\title{
Apakah kepuasan kerja guru di SMK PGRI 3 Cimahi dapat dipengaruhi lingkungan kerja non fisik?
}

(Does the work satisfaction of teachers in SMK PGRI 3 Cimahi can be influence of non physical work environment?)

\author{
Risna Cintiani', Hady Siti Hadijah ${ }^{2 *}$ \\ 1,2Program Studi Pendidikan Manajemen Perkantoran, \\ Fakultas Pendidikan Ekonomi dan Bisnis, Universitas Pendidikan Indonesia, \\ Jl. Dr. Setiabudhi No. 229 Bandung 40I32, Jawa Barat, Indonesia \\ Email : hady@upi.edu
}

\begin{abstract}
ABSTRAK
Terdapat banyak faktor yang dapat menyebabkan para guru mendapatkan kepuasan kerja di tempat mereka bekerja. Salah satunya adalah faktor lingkungan terutama faktor lingkungan non fisik yaitu keadaan lingkungan tempat kerja pegawai berupa suasana kerja yang harmonis antar bawahan dengan atasan (hubungan vertikal) serta antar sesama pegawai (hubungan horisontal). Penelitian ini bertujuan untuk mengetahui ada tidaknya pengaruh faktor lingkungan non fisik terhadap kepuasan kerja guru pada sebuah SMK di Cimahi. Penelitian ini menggunakan metode explanatory survey. Data yang diperoleh melalui angket yang disebar kepada 51 guru terpilih sebaGai sampel. Alat statistik yang digunakan adalah regresi linier sederhana. Hasil penelitian menunjukkan bahwa terdapat pengaruh lingkungan kerja non fisik terhadap kepuasan kerja guru di SMK PGRI 3 Cimahi.
\end{abstract}

Kata Kunci: kepuasan kerja, lingkungan kerja non fisik

\begin{abstract}
There are many factors that can cause teachers to get job satisfaction where they work. One of them is environmental factor especially non environment physical factor that is environment of work place of employee in the form of harmonious work atmosphere between subordinate with superior (vertical relationship) and between fellow employees (horizontal relationship). This study aims to determine whether or not the influence of non-physical environmental factors on job satisfaction of teachers in a vocational school in Cimahi. This research use explanatory survey method. Data obtained through questionnaires distributed to 51 selected teachers as sample. The statistical tool used is simple linear regression. Result of research indicate that there is influence of non working physical environment to job satisfaction of teacher at SMK PGRI 3 Cimahi.
\end{abstract}

Keywords: job satisfaction, non physical work environment

Received: Agustus 2017, Revision: November 2017, Published: Januari 2018

\footnotetext{
* Corresponding author Copyright (C) 2018, EISSN 2656-4734
} 


\section{PENDAHULUAN}

Peran guru tidak bisa diabaikan karena tanpa guru pendidikan tidak dapat terlaksana.Keberhasil an guru dalam melaksanakan tugasnya tidak terlepas dari sikap emosional yang menyenangkan dan mencintai pekerjaannya yang tercermin pada moral kerja, kedisiplinan dan prestasi kerja. Sikap ini menurut Hasibuan disebut kepuasan kerja (Hasibuan 2007, hlm. 202).

Kepuasan kerja guru SMK PGRI 3 sudah relative baik, tetapi masih belum optimal yang terlihat dari ketidakhadiran guru dimana dalam setiap bulan selalu ada guru yang tidak hadir tanpa keterangan/alasan.

Tabel 1. 1

Rekapitulasi Ketidakhadiran Guru Tanpa Alasan Di SMK PGRI 3 Cimahi

\begin{tabular}{|c|c|c|c|c|c|c|}
\hline \multirow[t]{2}{*}{ Bulan } & \multicolumn{2}{|c|}{2013} & \multicolumn{2}{|c|}{2014} & \multicolumn{2}{|c|}{2015} \\
\hline & 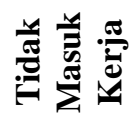 & 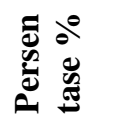 & 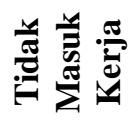 & 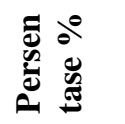 & 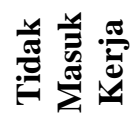 & 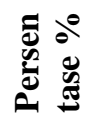 \\
\hline Januari & 3 & 6 & 2 & 4 & 3 & 6 \\
\hline Februari & 4 & 8 & 2 & 4 & 1 & 2 \\
\hline Maret & 6 & 12 & 4 & 8 & 2 & 4 \\
\hline April & 4 & 8 & 3 & 6 & 1 & 2 \\
\hline Mei & 6 & 8 & 3 & 6 & 5 & 2 \\
\hline Juni & 3 & 6 & 5 & 10 & 2 & 4 \\
\hline Juli & 2 & 4 & 6 & 12 & 3 & 6 \\
\hline Agustus & 4 & 8 & 5 & 10 & 4 & 8 \\
\hline September & 6 & 12 & 4 & 8 & 2 & 4 \\
\hline Oktober & 3 & 2 & 4 & 8 & 3 & 6 \\
\hline November & 7 & 14 & 3 & 6 & 1 & 2 \\
\hline Desember & 1 & 2 & 3 & 6 & 2 & 4 \\
\hline
\end{tabular}

Sumber : Data dari sekolah. Ket. : Jumlah guru 51 orang. Satuan tidak masuk kerja adalah orang/hari

Belum optimalnya kepuasan kerja guru dapat dilihat juga dari masih adanya guru yang merasa terbebani bila diberi tugas tambahannya, pikiran dan perasaan yang kurang fokus pada pekerjaan menyiapkan persiapan mengajar dan guru hanya menyampaikan sedikit pelajaran selebihnya memberikan tugas.

Untuk itu, perlu diperhatikan faktor- faktor yang mempengaruhi kepuasan kerja guru. Salah satu faktor yang diduga paling mempengaruhi kepuasan kerja guru adalah faktor lingkungan kerja non fisik. Menurut Duane $P$. Schultz dan Sydney E. Schultz dalam Mangkunegara (2005, hlm 105), "Lingkungan kerja non fisik adalah semua aspek fisik psikologis kerja dan peraturan kerja yang dapat mempengaruhi kepuasan kerja dan pencapaian kinerja." Lingkungan kerja non fisik merupakan keadaan lingkungan tempat kerja pegawai yang berupa suasana kerja yang harmonis dimana terjadi hubungan atau komunikasi antara bawahan dengan atasan serta hubungan antar sesama pegawai (Sedarmayanti, 2001:hlm 31). Adanya suasana kerja dan komunikasi yang harmonis, diharapkan guru akan merasa betah di tempat kerja sehingga mampu menumbuhkan sikap kedisiplinan yang tinggi, moral kerja yang baik serta dapat menunjukkan prestasi yang tinggi. Lingkungan kerja yang kondusif diduga dapat memberikan kepuasan kerja guru yang berakibat pada peningkatan kinerja guru. Sedangkan 
lingkungan kerja yang tidak kondusif dikhawatirkan dapat menurunkan kepuasan kerja guru yang akan berakibat pada penurunan kinerja guru.

Berdasarkan pemaparan di atas, peneliti tertarik untuk mengetahui bagaimana kondisi lingkungan kerja nonfisik dan kepuasan kerja guru di SMK PGRI 3 Cimahi, serta adakah pengaruh lingkungan kerja nonfisik terhadap kepuasan kerja guru di SMK PGRI 3 Cimahi.

\section{TINJAUAN PUSTAKA}

\section{Lingkungan Kerja Non Fisik}

Lingkungan non fisik ini merupakan kelompok lingkungan kerja yang tidak bisa diabaikan karena menyangkut suatu hubungan antara karyawan dan pimpinan maupun sesama karyawan. Lingkungan kerja non fisik adalah lingkungan kerja yang menyenangkan dalam arti tercapainya hubungan kerja yang harmonis antara sesama karyawan juga dengan atasan. Menurut Nitisemito (2000, hlm 171-173), "Perusahaan hendaknya dapat mencerminkan kondisi yang mendukung kerja sama antara tingkat atasan bawahan maupun yang memiliki status jabatan yang sama di perusahaan. Kondisi yang hendaknya diciptakan adalah suasana kekeluargaan, komunikasi yang baik, dan pengendalian diri". Kondisi yang dimaksudkan merupakan lingkungan kerja non fisik.

Menurut Sedarmayanti (2001, hlm 31), “ Lingkungan kerja non fisik adalah semua keadaan yang terjadi yang berkaitan dengan hubungan kerja, baik hubungan dengan atasan, sesama rekan kerja ataupun dengan bawahan". Seiring dengan pernyataan di atas, Sondang P. Siagian (2006, hlm205) menyatakan bahwa, "Lingkungan kerja non fisik adalah lingkungan kerja yang menyenangkan dalam artian terciptanya hubungan kerja yang harmonis antara pegawai dan atasan." Sementara itu, Ignatius Wursanto (2009, hlm 45) menyatakan bahwa, "Lingkungan kerja non fisik merupakan lingkungan kerja yang tidak dapat ditangkap dengan panca indra."

Lingkungan kerja non fisik yang dimaksud dalam penelitian ini adalah lingkungan dimana para pegawai bekerja yang di dalamnya terdapat interaksi sosial berupa hubungan kerja. Hubungan tersebut berupa hubungan formal dan non formal yang dilakukan bawahan terhadap atasan maupun sesama bawahan, dalam usaha untuk memupuk kerja sama yang intim dan selaras sebagai sarana untuk mencapai tujuan yang telah ditentukan. Keberhasilan pegawai dalam menjalin hubungan baik di dalam maupun di luar pekerjaan ditentukan oleh sikap ramah, saling menghargai, serta memperhatikan kepentingan orang lain sebagai wujud dari hubungan sosial. Hal ini diperlukan pimpinan yang dapat memberikan perhatian dan pengarahan sehingga dapat mendorong hubungan yang serasi antar karyawan. Hubungan antar sesama karyawan sangat perlu sekali diperhatikan karena apabila seorang karyawan sudah merasa tidak nyaman dengan teman kerjanya dipastikan karyawan tersebut akan malas untuk bekerja.

Berdasarkan pendapat diatas, maka dapat dikatakan bahwa lingkungan kerja non fisik adalah lingkungan kerja yang tidak dapat ditangkap dengan panca indera manusia, tetapi hanya dapat dirasakan oleh para pekerja melalui hubungan-hubungan sesama pekerja maupun dengan atasan.

Mengenai lingkungan kerja non fisik Agus Ahyari (2002, hlm 128) menyatakan bahwa yang termasuk lingkungan kerja non fisik yaitu hubungan antar manusia (Human relations). Berdasarkan aktivitasnya human relations diartikan dalam arti sempit dan luas. Darsowiryono Soekadi (2001, hlm 2) menyatakan bahwa human relations dalam arti luas adalah interaksi antara seseorang dengan orang lain, dalam segala situasi dan dalam semua bidang kehidupan untuk memperoleh kepuasan hati. Sedangkan Human Relations dalam arti sempit hakekatnya sama, yaitu interaksi antara seseorang dengan orang lain, hanya saja aktivitas interaksi itu 
terbatas dalam suatu situasi kerja dan dalam suatu organisasi tertentu. Human relations merupakan hubungan yang saling mempengaruhi seseorang sehingga terjadilah interaksi sosial. Adapun interaksi sosial yang memungkinkan terjadinya komunikasi di dalam organisasi umumnya terdiri dari: (1) Hubungan antar karyawan. Dalam suatu organisasi antara karyawan satu tengan karyawan yang lainnya pastilah saling melakukan komunikasi. Hal ini merupakan suatu hal yang harus dilakukan berkenaan dengan pekerjan yang menjadi tanggung jawabnya. Suatu pekerjaan yang membutuhkan kerjasama dan bantuan karyawan lain mutlak diselesaikan dengan lancar dan baik. Oleh karena itu, hubungan antar karyawan perlu dibina dan dipelihara sebaik mungkin untuk menunjang usaha pencapaian tujuan organisasi tersebut. (2) Hubungan karyawan dengan atasan/pimpinan. Hubungan karyawan dengan pimpinan tidak kalah pentingnya dengan hubungan antar karyawan. Dalam hubungan karyawan dengan pimpinan terdapat hubungan timbal balik. Pimpinan senantiasa memberikan perintah disertai dengan petunjuk pelaksanaan suatu pekerjaan, memberikan motivasi terhadap bawahan, mengikut sertakan bawahan dalam hal pembuatan keputusan. Sementara itu karyawan/bawahan melaksanakan apa yang diperintahkan pimpinan, bertanggungjawab terhadap pekerjaannya kepada pimpinan, memberikan ide, saran, kritik yang membangun dan lain-lain. yang perlu diperhatikan dalam hubungan antara karyawan dengan pimpinan adalah tercapainya keselarasan kerja antara pimpinan dengan karyawan sehingga dapat tercapainya keselarasan kerja antara pimpinan dengan karyawan dan tercipta suasana kerja yang menyenangkan.

Dari penjelasan lingkungan kerja non fisik tersebut maka dapat ditarik kesimpulan bahwa yang menjadi indikator lingkungan kerja non fisik adalah hubungan sesama karyawan, hubungan pimpinan dan bawahan. Selanjutnya pengertian human relations yang peneliti maksudkan di sini adalah human relations dalam arti sempit, yaitu human relations di dalam suatu organisasi dalam upaya menimbulkan semangat kerja, kerjasama, dan kepuasan kerja guru. Pengertian lingkungan kerja no fisik mengandung pada pengertian hubungan antar manusia (guru) yang terjadi di sekolah tengan indikator yang digunakan adalah 1) hubungan antar guru 2) hubungan guru dengan atasan (kepala sekolah dan wakil-wakil).

Kepuasan Kerja

Salah satu sarana penting pada manajemen sumber daya manusia dalam sebuah sekolah adalah terciptanya kepuasan kerja guru. Kepuasan kerja menunjukkan kemampuan organisasi dalam memenuhi kebutuhan pegawainya. Kepuasan kerja pada dasarnya merupakan sesuatu yang bersifat individual. Setiap individu memiliki tingkat kepuasan yang berbeda-beda sesuai dengan sistem nilai yang berlaku pada dirinya. Semakin tinggi penilaian terhadap kegiatan dirasakan sesuai dengan keinginan individu, maka tinggi kepuasannya terhadap kegiatan tersebut. Sebaliknya, semakin rendah penilaian individu terhadap pekerjaannya maka semakin rendah kepuasan kerjanya.

Pengertian kepuasan telah di kemukakan oleh beberapa ahli, diantaranya yaitu dari Keith Davis (1985, hlm 96) dalam Mangkunegara (2011, hlm 117) yang menyatakan bahwa "job satisfaction is the favorablenes or unfavorablenes with employes view their work". (Kepuasan kerja adalah perasaan menyokong atau tidak menyokong yang dialami pegawai saat bekerja). Menurut Veithzal Rivai (2009, hlm 856), “ Kepuasan adalah evaluasi yang menggambarkan seseorang atas perasaan sikapnya senang atau tidak senang, puas atau tidak puas dalam bekerja". Selanjutnya Hani Handoko (2007, hlm 193) juga mengatakan bahwa, "Kepuasan kerja adalah keadaan emosional yang menyenangkan dan tidak menyenangkan dengan mana para pegawai memandang pekerjaan mereka". Sementara itu menurut Luthans (2006, hlm 243), "Kepuasan 
kerja yaitu merupakan hasil dari persepsi pegawai tentang seberapa baik pekerjaan mereka menyediakan hal yang dianggap penting”.

Melayu Hasibuan (2007, hlm 202) menyatakan bahwa, "Kepuasan kerja adalah sikap emosional yang menyenangkan dan mencintai pekerjaannya. Sikap ini dicerminkan oleh moral kerja, kedisiplinan dan prestasi kerja. Kepuasan kerja dinikmati dalam pekerjaan, luar pekerjaan dan kombinasi dalam dan luar pekerjaan. Kepuasan kerja dalam pekerjaan adalah kepuasan kerja yang dinikmati dalam pekerjaan dengan memperoleh pujian hasil kerja, penempatan, perlakuan, peralatan dan suasana lingkungan kerja yang baik".

Berdasarkan pendapat beberapa ahli di atas dapat disimpulkan bahwa kepuasan kerja adalah suatu sikap emosional yang dimiliki oleh seseorang baik positif maupun negatif mengenai pekerjaannya dan tercermin pada kedisiplinan, moral kerja, serta prestasi seseorang.

Pengukuran kepuasan kerja yang dimiliki setiap orang pada dasarnya sulit diukur. Karyawan sebagai perencana, pelaksana dan pengendali dalam mewujudkan tujuan perusahaan memiliki kepuasan kerja yang berbeda-beda. Oleh karena itu sikap dan perasaan yang ada dalam karyawan harus selalu dibina tengan baik. Malayu S.P Hasibuan (2007, hlm 202) menjelaskan bahwa tolok ukur tingkat kepuasan yang dimiliki setiap individu berbeda-beda. Indikator kepuasan kerja hanya diukur dengan kedisiplinan, moral kerja, dan turnover kecil maka secara relatif kerja karyawan baik. Sebaliknya jika kedisiplinan, moral kerja, dan turnover karyawan besar maka kepuasan kerja karyawan besar maka kepuasan kerja karyawan di perusahaan kurang.

Pengukuran kepuasan kerja sangat bervariasi, baik dari segi analisis statik maupun pengumpulan datanya. Informasi yang didapat dari kepuasan kerja bisa melalui tanya jawab langsung secara perorangan, dengan angket ataupun pertemuan suatu kelompok kerja. Jika menggunakan tanya jawab atau interview sebagai alatnya, pegawai diminta untuk merumuskan perasaannya terhadap aspek-aspek pekerjaan (self report). Hal ini sesuai tengan pendapat Davis dan Newstrom (1985, hlm 114), yang menjelaskan bahwa survei kepuasan kerja dapat dilakukan dengan 1) Survei Objektif, digunakan untuk mengukur kepuasan kerja pegawai dengan cara menyediakan pertanyaan danpilihan jawaban sedemikian rupa sehingga pegawai hanya memilih jawaban yang telah disediakan dan menandai jawaban yang paling mewakili perasaan mereka. Manfaat dari survei ini mudah dilakukan dan dianalisis secara statistik, sehingga tidak memakan banyak waktu. 2) Survei Deskriptif, menyajikan pertanyaan tentang berbagai topik tetapi memberikan keleluasaan bagi pegawai untuk menjawabnya dengan pendapat mereka sendiri. Pendekatan ini dengan metode wawancara sehingga lebih memungkinkan pegawai untuk mengungkap perasaan, pikiran, dan keinginan mereka sepenuhnya. Pengukuran Kepuasan Kerja dengan Kuesioner Minnesota yang dikembangkan oleh Weiss, Dawis, dan England pada tahun 1967. Skala ini terdiri dari pekerjaan yang dirasakan sangat tidak puas, tidak puas, netral, memuaskan, dan sangat memuaskan. Pegawai diminta memilih satu alternatif jawaban yang sesuai dengan kondisi pekerjaannya.

Dalam penelitian ini peneliti menggunakan tingkat kedisiplinan, moral kerja, dan prestasi kerja sebagai indikator kepuasan kerja guru sesuai dengan pendapat Malayu P. Hasibuan (2007, hlm 202) dengan jawaban terdiri dari 5 opsi seperti pada kuesioner Minnesota Pengaruh Lingkungan Kerja Fisik Non Fisik terhadap Kepuasan Kerja

Lingkungan kerja atau kondisi kerja, merupakan salah satu aspek yang harus di perhatikan oleh perusahaan karena hal ini akan berpengaruh pada kepuasan kerja. Untuk itu, setiap organisasi harus lebih detail dalam memperhatikan lingkungan kerja agar tujuan organisasi dapat tercapai sesuai dengan yang diinginkan. Lingkungan kerja akan mempengaruhi para 
pegawai dalam bekerja sehingga baik secara langsung maupun tidak langsung akan berpengaruh terhadap kepuasan kerja dan berpengaruh pula terhadap produktifitas organisasi. Hal ini sesuai dengan pernyatan Graham Wilson (2008, hlm. 227) yang menyatakan bahwa "Lingkungan kerja adalah salah satu faktor yang mempengaruhi kepuasan kerja". Demikan juga diungkapkan Stephen P. Robbins (2008, hlm. 110) bahwa "Lingkungan kerja seorang pegawai sangat mempengaruhi tingkat kepuasan kerjanya. Hal ini akan berakibat pada keseluruhan kinerja pegawai yang bersangkutan".

Lingkungan kerja yang diduga sebagian besarnya mempengaruhi kepuasan kerja adalah lingkungan kerja non fisik. Menurut Duane P. Schultz dan Sydney E. Schultz dalam Mangkunegara (2005, hlm 105). "Lingkungan kerja non fisik adalah semua aspek fisik psikologis kerja dan peraturan kerja yang dapat mempengaruhi kepuasan kerja dan pencapaian kinerja". Lingkungan kerja non fisik merupakan keadaan lingkungan tempat kerja pegawai yang berupa suasana kerja yang harmonis dimana terjadi hubungan atau komunikasi antara bawahan dengan atasan serta hubungan antar sesama pegawai (Sedarmayanti, 2001 : 31). Adanya suasana kerja dan komunikasi yang harmonis, diharapkan guru akan merasa betah di tempat kerja sehingga mampu menumbuhkan sikap kedisiplinan yang tinggi, moral kerja yang baik serta dapat menunjukkan prestasi yang tinggi. Lingkungan kerja non fisik yang meliputi hubungan dan kerjasama yang baik tersebut dapat meningkatkan kepuasan kerja (Bani, 2012; Robby,2015;Hendiana,2013)

Adapun paradigma penelitian kepuasan kerja di atas dapat terlihat pada Gambar 1.1. di bawah ini:

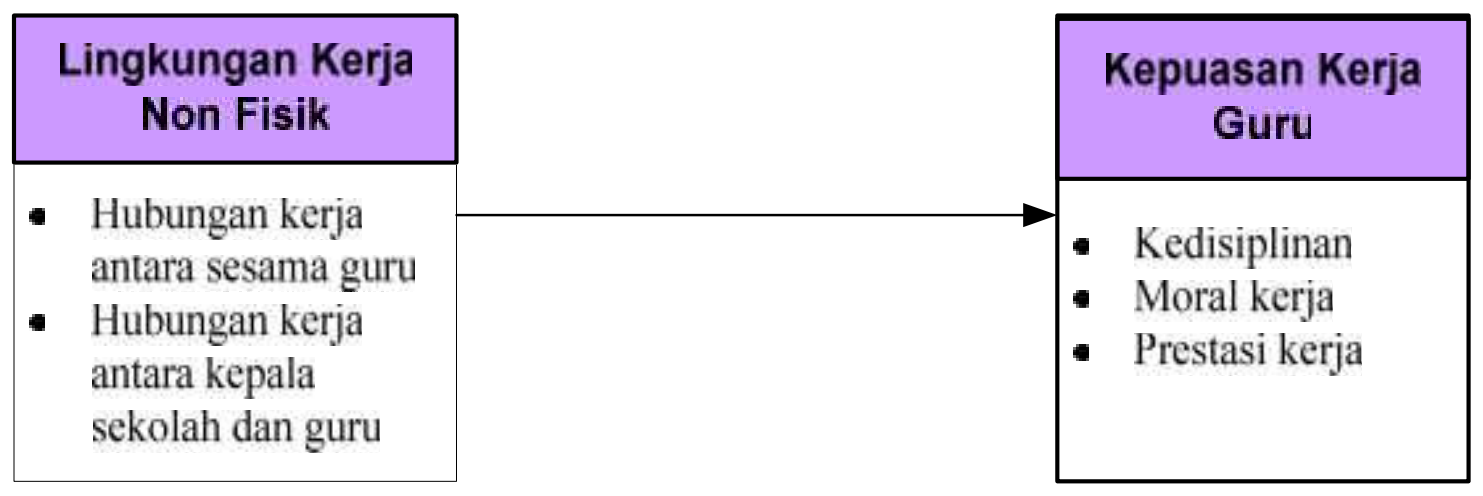

\section{Gambar 1.1 Paradigma Penelitian}

Gambar 1.1. memperlihatkan hubungan kausalitas lingkungan kerja non fisik tengan kepuasan kerja guru. Kepusan kerja guru yang tinggi dapat disebabkan lingkungan kerja non fisik yang baik. Hipotesis yang dapat dirumuskan adalah terdapat pengaruh lingkungan kerja non fisik terhadap kepuasan kerja guru, artinya semakin baik lingkungan kerja non fisik maka semakin tinggi kepuasan kerja para guru di SMK PGRI 3 Cimahi.

\section{METODOLOGI}

Metode penelitian yang akan digunakan adalah metode deskriftif verfikatif. Pengujian hipotesisnya dilakukan melalui Model Persamaan RegresiSederhana dengan menggunakan software SPSS. Populasinya adalah seluruh guru yang ada di SMK PGRI 3 Cimahi yang berukuran 51 orang yang juga bertindak sebagai responden. Metoda sampel yang digunakan 
adalah sampel ilmiah (sensus), artinya semua anggota populasi dijadikan anggota sampel.Sampel Teknik pengumpulan data dilakukan dengan menggunakan empat cara yaitu studi lapangan melalui observasi; wawancara; kuesioner; studi kepustakaan (Sugiyono, 2013). Uji validitas instumennya menggunakan koefisien korelasi dan uji reliabilitasnya menggunakan formula koefisien Alpha Cronbach. Opsi jawaban dari item yang termasuk variabel lingkungan kerja non fisik adalah sangat tidak baik, tidak baik, sedang, baik, dan sangat baik; sedangkan untuk variabel kepuasan adalah sangat tinggi, tinggi, sedang, rendah sangat rendah.

\section{HASIL PENELITIAN}

Kuesioner penelitian yang terdiri atas 28 item yang disebarkan untuk mengumpulkan data pada penelitian ini telah melalui pengujian validitas dan reliabilitas dimana item pernyataan memiliki indeks validitas $\geq 0,276$ dan reliabilitas $\geq 0,60$, artinya semua data telah valid dan reliabel

Hasil penelitian berdasarkan jawaban angket yang terkumpul dari responden mendeskripsikan bahwa gambaran kondisi lingkungan kerja non fisik SMK PGRI 3 Cimahi berada pada kategori baik dan tingkat kepuasan kerja guru di SMK PGRI 3 Cimahi pada kategori tinggi.

Selanjutnya hasil pengujian hipotesis atas pertanyaan ada tidaknya pengaruh lingkungan kerja non fisik terhadap kepuasan guru diperoleh nilai $t_{\text {hitung }}$ sebesar 6,152 lebih besar dari $t_{\text {kritis }}$ 1.676 sehingga dapat disimpulkan bahwa hipotesisyang berbunyi terdapat pengaruh lingkungan kerja non fisik terhadap kepuasan kerja guru di SMK PGRI 3 Cimahi diterima. Hasil perhitungankoefisien regresi varibel lingkungan kerja non fisik terhadap variabel kepuasan kerja guru sebesar 0,942.

\section{KESIMPULAN}

Berdasarkan hasil analisis dan pembahasan sebagaimana telah diuraikan, dapat disimpulkan bahwa lingkungan kerja non fisik berpengaruh terhadap kepuasan kerja guru di SMK PGRI 3 Cimahi. Hal ini menunjukkan bahwa tinggi rendahnya kepuasan kerja guru tergantung pada kondusifnya lingkungan kerja non fisik di SMK PGRI 3 Cimahi.

Lingkungan kerja non fisik yang dikelola dengan baik dan dijaga kondusifitasnya secara positif akan semakin meningkatkan kepuasan kerja guru di SMK PGRI 3 Cimahi, sehingga kinerja guru akan semakin meningkat. Sekolah harus menghindari kebijakan yang berakibat buruk, misalnya dapat menyebabkan konflik antar guru seperti dalam hal membuat jadwal jam mengajar yang cenderung berpotensi terjadi perebuatan jam mengajar. Sekolah sebaiknya mengadakan kegiatan semacam kegiatan family gathering atau outbond minimal 1 tahun sekali agar dapat mendekatkan hubungan dan memperlancar komunikasi antara atasan dan bawahan serta rekan sejawat. Sebaiknya juga kepala sekolah selalu membuka komunikasi yang baik dan lebih bersahabat dengan para guru tanpa mengurangi kewibawaannya serta tetap menjaga rasa saling menghormati dalam setiap aktifitas yang dilakukan di dalam maupun di luar sekolah.

Lingkungan kerja non fisik yang baik (kondusif) dapat meningkatkan kedisiplinan yang terlihat dari berkurangnya ketidakhadiran guru tanpa keerangan; selain itu moral kerja, dan prestasi guru menjadi lebih meningkat. 


\section{DAFTAR PUSTAKA}

Ahyari, Agus, (2002). Manajemen Produksi Dan Pengendalian Produksi. Yogyakarta: BPFE.

Fath, Robby Alam, 2015. Pengaruh Lingkungan Kerja Non Fisik dan Karakteristik Pekerjaan Terhadap Kepuasan Kerja ( Studi Pada Karyawan Hotel bintang Dua di Yogyakarta).

Handoko, Hani. T., (2007). Mengukur Kepuasan Kerja. Jakarta: Erlangga.

Hasibuan, Malayu S.P., (2007).Manajemen Sumber Daya Manusia. Jakarta: PT. Bumi Aksara.

Hendiana, 2013. Pengaruh Kondisi Kerja terhadap Kepuasan Kerja Karyawan pada Divisi Sumber Daya Manusia PT. KAI (Persero ) Bandung.

Luthans, Fred, (2006). Perilaku Organisasi, Edisi Sepuluh, Diterjemahkan Oleh : Vivin, dkk. Yogyakarta: Andi.

Mangkunegara, Anwar Prabu, (2005). Sumber Daya Manusia Perusahaan. Bandung: Remaja Rosda Karya.

Mangkunegara, Anwar Prabu, (2011). Manajemen Sumber Daya Manusia Perusahaan. Bandung: Remaja Rosda Karya.

Nitisemito, Alex S., (2000). Manajemen Personalia: Manajemen Sumber Daya Manusia. Jakarta: Ghalia Indonesia.

Newstroom, Davis, (1985). Perilaku Dalam Organisasi. Jakarta: Erlangga.

Nurcahya, Bani, 2012. Pengaruh Lingkungan Kerja Non Fisik terhadap Kepuasan Kerja Pegawai Pusat Pengembangan dan Pemberdayaan Pendidik dan Tenaga Kependidikan Ilmu Pengetahuan Alam.

Rivai,Veithzal, (2009). Manajemen Sumber Daya Manusia Untuk Perusahaan. Jakarta: Rajawali Pers.

Robins, Stephen P, (2008). Organisasi Behaviour dan kepuasan Kerja, Tenth Editions. New Jersey: Prentice Hail.

Sedarmayanti, (2001). Sumber Daya Manusia Dan Produktifitas Kerja. Jakarta: Mandar Maju.

Siagian,Sondang P., (2006). Manajemen Sumber Daya Manusia. Jakarta: Bumi Aksara.

Soekadi, Darsowiryono, (2001). Peranan Komunikasi Dalam Organisasi. Surakarta: Bumi Ketingan Surakarta.

Sugiyono, (2013). Metode Penelitian Pendidikan.Bandung: Alfabeta.

Wilson, Graham, (2008). Kondisi Kerja Dan Faktor Kepuasan kerja. Jakarta: Prentice Hail.

Wursanto, Ignatius, (2009). Dasar-dasar Ilmu Organisasi. Yogyakarta: Andi. 